\title{
Determination of the Elements of Soil Water Balance for Wheat (Triticum aestivum L.) Under Shallow Water Table
}

\author{
Salloom B. Salim ${ }^{1}$, Luma S. Khudhair ${ }^{2}$ \\ ${ }^{1}$ Department of Soil Sciences and Water Resources, College of Agriculture, Baghdad University, Baghdad, Iraq \\ ${ }^{2}$ Extension Specialists, Ministry of Agriculture, Baghdad, Iraq
}

\section{Email address:}

salloom_s@yahoo.com (S. B. Salim)

\section{To cite this article:}

Salloom B. Salim, Luma S. Khudhair. Determination of the Elements of Soil Water Balance for Wheat (Triticum aestivum L.) Under Shallow Water Table. International Journal of Applied Agricultural Sciences. Vol. 1, No. 3, 2015, pp. 84-90. doi: 10.11648/j.ijaas.20150103.17

\begin{abstract}
To determine the elements of soil water balance equation during the growing season detailed description for calculating daily contribution rates to evapotranspiration of wheat $(E T)$ from applied irrigation water $\left(E T_{r}\right)$ and upward flux capillarity $\left(E T_{c}\right)$, depth of applied irrigation water $(D A I W)$, change in water storage $(\Lambda s)$ and cumulative evapotranspiration $\left(E T_{\text {cum }}\right)$ were algorithmed in this study. Irrigation water was applied to three different depths $30,30-60$ and $60 \mathrm{~cm}$ at three different depletion rates 50, 70 and 90\% from plant available water. Wheat ET ranged from 428.49 to $522.12 \mathrm{~mm}$. Contributions to ET from applied irrigation water ranged from 334.20 to $496.50 \mathrm{~mm}$ and increased with increasing irrigation depth. Contributions to ET from upward flux capillarity ranged from 25.61 to $96.59 \mathrm{~mm}$ and decreased with increasing irrigation depth. Contributions to ET from applied irrigation water decreased with increasing depletion rate whilst contributions to ET from upward flux capillarity increased with increasing depletion rates. Daily rate contribution to evapotranspiration from irrigation water ranged from 2.15 to $3.20 \mathrm{~mm}$.d-1 and from capillary flux ranged from 0.16 to 0.61 mm.d-1.
\end{abstract}

Keywords: Shallow Water Table, Water Balance, Depletion Rate, Capillary Flux, Cumulative Evapotranspiration

\section{Introduction}

Surface water resources in Iraq of the Euphrates and the Tigris rivers declined sharply during the last two decades thus creating severe water scarcity in most irrigated areas and reducing Falkenmark water scarcity index from $2648 \mathrm{~m} 3$ per capita per year for the 20th century to $989 \mathrm{~m} 3$ per capita per year for the 21st century (Al-Shahrabli 2009, Saleh 2010). Limited water resources is the most effecting factor governing agriculture production and rising instability of food security. Understanding the magnitude and dynamics of applied irrigation water is crucial to development of technological options for sustainable management of available water resources (Strauss et al., 2010). The general soil water balance equation is given as:

$$
I+C+P-\Delta S=E T+R+D
$$

where $I$ is irrigation, $\mathrm{C}$ is upward capillary flux, $P$ is precipitation, $\Delta S$ is change in soil water storage, $E T$ is evapotranspiration, $R$ is runoff losses and $D$ is deep drainage losses. Components ET, $P, /$ and $C$ are always positive, $R$ and
$D$ are always negative but $\Delta S$ can be positive or negative. Negative $\Delta S$ indicates depletion of soil-water storage. In situ assessment of the hydrological mass flux is essential in food security research (Owonubi et al, 1991) and irrigation water and land management (Brown et al., 2012). Methodologies, experimental techniques and modeling at the field scale facilitate applying the right amount of irrigation water at the right time that can based on soil, plant and/or atmospheric measurements and is commonly known as scientific irrigation scheduling (Lieb et al., 2002). Metering the irrigation system laterals at the field scale allows precise application of the deficit in plant available water between irrigations to the effective root zone (ERZ) and minimizing run off and deep drainage losses ( Moiwo et al., 2011). In arid climates the contribution to plant needs from precipitation is negligible since rainfall intensity is low and mean annual precipitation is less than $100 \mathrm{~mm}$. Precipitation is always measured easily and precisely by rain gauge .

In most studies of soil water balance irrigation water is applied to replenish depleted plant available water to field capacity. Eiasu et al. (2006) applied four water depletion levels $(20,40,60$ and $80 \%$ of the plant available soil water) in the top $0.8 \mathrm{~m}$ root zone and noticed that plant roots 
extracted most soil water from the top $0.4 \mathrm{~m}$ soil layer. The depletion rate at which water content is determined depends on plant and soil characteristics and its critical to water productivity (Jalota et al., 2006). The difference in stored water in ERZ requires the determination of initial water content before planting besides final water content after harvest. When initial water content in the ERZ exceeds assumed deficit then stored water is positive. Even gravimetric method for determining water content is basic but it represents the yard stick for other methods thus can be used to monitor change in water content during irrigation (Odhiambo and Bomke, 2007). When water is applied to satisfy plant evapotranspiration only then no percolation below the root zone occurs and deep drainage losses is set to zero. To insure zero deep drainage losses tensiometrs can be installed at discrete depth intervals including at least the upper and the lower boundary of the ERZ and the vicinity of the capillary fringe of a shallow water table to determine soil water potential and flux direction (Saini and Ghildyal, 1977). Contribution form ground water to plant evapotranspiration can be determined according to Richard's equation (Richard's, 1931). In case of shallow water table the capillary flux is determined from the change in water content in the layer designated by tensiometer placement at the lower boundary of ERZ as its upper boundary and at the water table ( capillary fringe) as its lower boundary. This study aimed to detailed description of the components of soil water balance equation for determining daily water use by growing crops under shallow water table and providing all equations necessary for calculations.

\section{Materials and Methods}

This study was performed in the experimental field of the College of Agriculture/ Baghdad University located at $33^{\circ} 20^{\prime}$ longitude north , $44^{\circ} 12^{\prime}$ latitude east and $32 \mathrm{~m}$ altitude during 2008-2009 wheat growing season in Iraq. Wheat (Triticum aestivum L.) seeds were planted at a rate of $130 \mathrm{~kg}$. ha-1 on 27/11/2008 at a depth of $5 \mathrm{~cm}$ in grain drill rows and was harvested on 3/5/2009. Treatments included three levels of depletion rates 50, 70, and 90\% from plant available water (PAW) and three irrigation depths [Depth of Effective Root Zone (ERZ)]; $30 \mathrm{~cm}$ from planting to harvest, $30 \mathrm{~cm}$ from planting to flowering then $60 \mathrm{~cm}$ from flowering to harvest and $60 \mathrm{~cm}$ from planting to harvest. The study was conducted in randomized complete block design with three replicates resulting in twenty seven $5 \mathrm{~m} \times 5 \mathrm{~m}$ experimental plots. Depth of applied irrigation water (DAIW) was calculated based on depletion rate from PAW in the ERZ. Water content changes was monitored gravimetrically using soil sampling tube $(2.5 \mathrm{~cm}$ OD) extending to $90 \mathrm{~cm}$ depth. It is necessary to mention here that this study required predetermination of the soil-water retension relationship. Amount of irrigation water for the first irrigation was assumed equal to the volume of water required to increase water content for the plot from initial water content before first irrigation ( $\theta_{\mathrm{O}}=0.205 \mathrm{~cm}^{3} . \mathrm{cm}^{-3}$ ) to field capacity ( $\theta_{f c}=0.401 \mathrm{~cm}^{3}{ }^{3} \mathrm{~cm}^{-3}$ ) for $30 \mathrm{~cm}$ depth. During first irrigation all plots received the same amount of irrigation water at the same time. Amount of irrigation water for the following irrigations was set equal to the volume of water required to increase water content of the ERZ for the plot from initial water content to field capacity. Values of initial water content at which 50, 70, and 90\% were depleted from plant available water (PAW) were calculated according to following formula:

$$
\theta_{o}=\theta_{f c}-(\% \text { depletion }) / 100 \times P A W
$$

or

$$
\theta_{o}=\theta_{p w p}+(\% \text { avialable }) / 100 \times P A W
$$

where $\theta_{o}, \theta_{f c}$, and $\theta_{\text {pwop }}$ are initial water content (volumetric water content measured at 24 hours before irrigation), volumetric water content at field capacity, volumetric water content at permanent wilting point $\left(0.181 \mathrm{~cm}^{3} . \mathrm{cm}^{-3}\right)$ and $P A W=\theta_{f c}-\theta_{o}$ is the plant available water for the ERZ.

Irrigation water was pumped into PVC piping net $(5 \mathrm{~cm}$ ID) with water meters measuring $\mp 0.001 \mathrm{~m}^{3}$ volume difference fixed at the end of plot lateral. Each lateral equipped with control valve located directly before the water meter. Except first irrigation water was applied at different times depending on depletion rates and irrigation depths. Gauge tensiometres were installed at 30,60 and $90 \mathrm{~cm}$ as shown in figure (1) for measuring matric potential $\left(\Psi_{m}\right)$ which was calculated according to Hanks and Ashcroft formula (Hanks and Ashcroft, 1980) as follows:

$$
\Psi_{m}=-10 \mathrm{~cm} \times G_{r}+z_{o}
$$

Where $G_{r}$ is gauge reading and $z_{o}$ is the vertical distance from the gauge to the center of ceramic cup of the tensiometer.

Total water potential was then calculated as the sum of matric and gravitational potentials to determining flow direction. Rate of ground water contribution to evapotranspiration was calculated for each irrigation according to Richard's equation from the change in soil water content in a layer designated by ERZ as Its upper boundary (30 or $60 \mathrm{~cm}$ ) and depth of tensiometer placement at $60 \mathrm{~cm}$ for $30 \mathrm{~cm} \mathrm{ERZ} \mathrm{and} \mathrm{at} 90 \mathrm{~cm}$ for $60 \mathrm{~cm} \mathrm{ERZ.}$

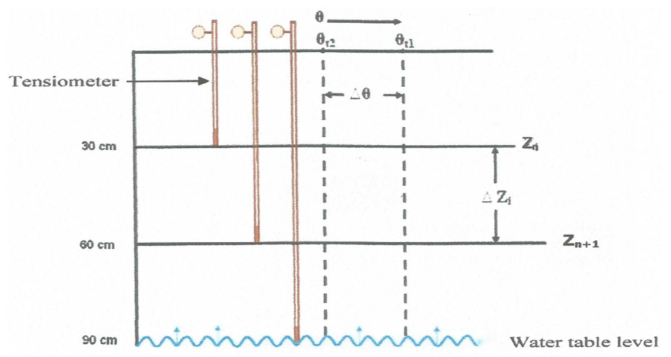

Fig. 1. Schematic representation for tensiometer placement and theoretical basis for depleted water content difference $(\Delta \theta)$ between two consecutive irrigations. 


\section{Results and Discussion}

Values of the components of the soil water balance equation during the growing season of wheat are given in table (1) for all treatments. Different numbers of irrigations were obtained depending on irrigation depth and depletion rate. For the $30 \mathrm{~cm}$ irrigation depth and $50 \%$ depletion rate ten irrigations were applied which represents the highest irrigation frequency during 158 days of wheat growing season compared with other treatments. Initial water content before each irrigation was necessary to determine differences in stored water before irrigation and must be accounted for when calculating DAIW for each irrigation according to the following formula:

$$
D A I W=\left(\theta_{f c}-\theta_{i}\right) z
$$

where $\theta_{f c}$ and $\theta_{i}$ are volumetric water content at field capacity $\left(0.401 \mathrm{~cm}^{3} . \mathrm{cm}^{3}\right)$ and initial water content before irrigation respectively. Measured initial water content values for each irrigation are shown in column (5). According to equation (5), total $D A I W$ during the growing season $\left(D A I W_{t}\right)$ was calculated as follows:

$$
D A I W_{t}=\sum_{i=1}^{k} D A I W
$$

where $\mathrm{i}$ is a counter for irrigation number and $\mathrm{k}$ is the total number of irrigations. Laboratory determined values of $\theta_{i}$ from soil water retention.

Table 1. Measured and calculated values of the components of the soil water balance equation.

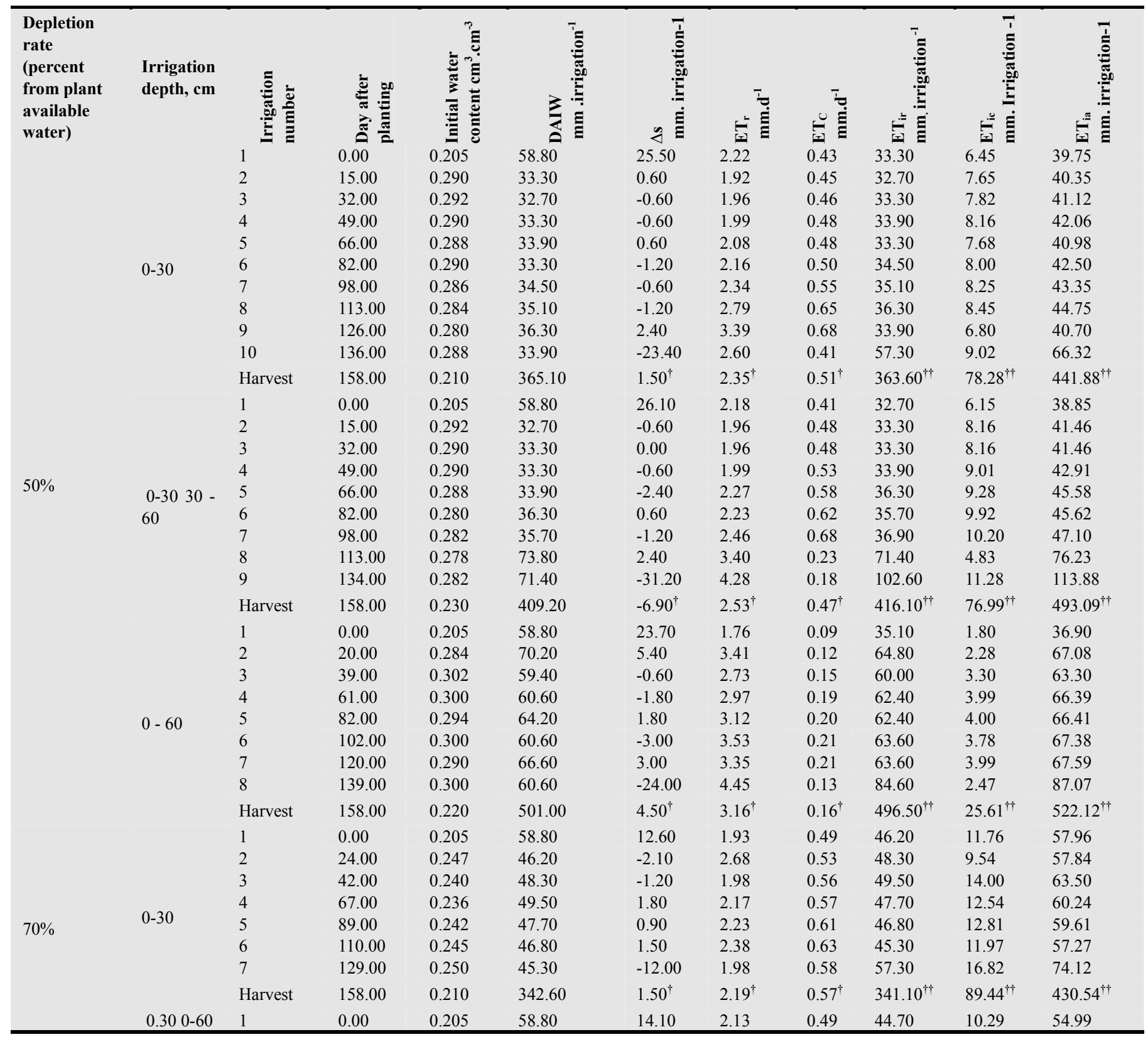




\begin{tabular}{|c|c|c|c|c|c|c|c|c|c|c|c|}
\hline \multirow[t]{23}{*}{$\begin{array}{l}\text { Depletion } \\
\text { rate } \\
\text { (percent } \\
\text { from plant } \\
\text { available } \\
\text { water) }\end{array}$} & \multirow[t]{9}{*}{$\begin{array}{l}\text { Irrigation } \\
\text { depth, cm }\end{array}$} & 2. & 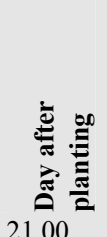 & 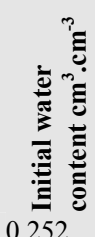 & 离 & 离 & 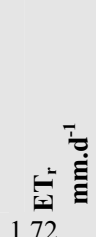 & 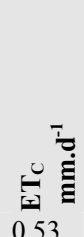 & : & 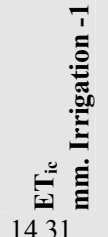 & 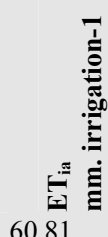 \\
\hline & & $\begin{array}{l}2 \\
3\end{array}$ & $\begin{array}{l}21.00 \\
48.00\end{array}$ & $\begin{array}{l}0.252 \\
0.246\end{array}$ & $\begin{array}{l}44.70 \\
46.50\end{array}$ & $\begin{array}{l}-1.80 \\
-3.60\end{array}$ & $\begin{array}{l}1.72 \\
1.79\end{array}$ & $\begin{array}{l}0.53 \\
0.56\end{array}$ & $\begin{array}{l}46.50 \\
50.10\end{array}$ & $\begin{array}{l}14.31 \\
15.68\end{array}$ & $\begin{array}{l}60.81 \\
65.78\end{array}$ \\
\hline & & 4 & 76.00 & 0.234 & 50.10 & 1.20 & 1.81 & 0.57 & 48.90 & 15.39 & 64.29 \\
\hline & & 5 & 103.00 & 0.238 & 97.80 & 1.20 & 3.22 & 0.24 & 96.60 & 7.20 & 103.80 \\
\hline & & 6 & 133.00 & 0.240 & 96.60 & -18.00 & 4.58 & 0.17 & 114.60 & 4.25 & 118.85 \\
\hline & & Harvest & 158.00 & 0.210 & 394.50 & $-6.90^{\dagger}$ & $2.54^{\dagger}$ & $0.43^{\dagger}$ & $401.40^{\dagger \dagger}$ & $67.12^{\dagger \dagger}$ & $468.52^{\dagger \dagger}$ \\
\hline & & 1 & 0.00 & 0.205 & 58.80 & 32.40 & 1.10 & 0.09 & 26.40 & 2.16 & 28.56 \\
\hline & & 2 & 24.00 & 0.259 & 85.20 & -0.60 & 3.30 & 0.15 & 85.80 & 3.90 & 89.70 \\
\hline & & 3 & 50.00 & 0.258 & 85.80 & 0.60 & 3.16 & 0.23 & 85.20 & 6.21 & 91.41 \\
\hline & \multirow[t]{7}{*}{$0-60$} & 4 & 77.00 & 0.259 & 85.20 & -1.20 & 3.20 & 0.28 & 86.40 & 7.56 & 93.96 \\
\hline & & 5 & 104.00 & 0.257 & 86.40 & -1.80 & 3.27 & 0.28 & 88.20 & 7.56 & 95.76 \\
\hline & & 6 & 131.00 & 0.254 & 88.20 & -24.60 & 4.18 & 0.19 & 112.80 & 5.13 & 117.93 \\
\hline & & Harvest & 158.00 & 0.213 & 489.60 & $4.80^{\dagger}$ & $3.03^{\dagger}$ & $0.20^{\dagger}$ & $484.80^{\dagger \dagger}$ & $32.52^{\dagger \dagger}$ & $517.32^{\dagger \dagger}$ \\
\hline & & 1 & 0.00 & 0.205 & 58.80 & 0.30 & 2.34 & 0.55 & 58.50 & 13.75 & 72.25 \\
\hline & & 2 & 25.00 & 0.206 & 58.50 & 1.80 & 2.18 & 0.57 & 56.70 & 14.82 & 71.52 \\
\hline & & 3 & 51.00 & 0.212 & 56.70 & -0.90 & 2.30 & 0.62 & 57.60 & 15.38 & 72.98 \\
\hline & \multirow[t]{7}{*}{$0-30$} & 4 & 76.00 & 0.209 & 57.60 & 0.90 & 1.62 & 0.67 & 56.70 & 23.45 & 77.85 \\
\hline & & 5 & 111.00 & 0.212 & 56.70 & -1.80 & 2.44 & 0.68 & 58.50 & 16.32 & 74.82 \\
\hline & & 6 & 135.00 & 0.206 & 58.50 & 12.30 & 2.01 & 0.56 & 46.20 & 12.88 & 59.08 \\
\hline & & Harvest & 158.00 & 0.247 & 346.80 & $12.60^{\dagger}$ & $2.15^{\dagger}$ & $0.61^{\dagger}$ & $334.20^{\dagger \dagger}$ & $96.59^{\dagger \dagger}$ & $428.49^{\dagger \dagger}$ \\
\hline & & 1 & 0.00 & 0.205 & 58.80 & 0.30 & 2.44 & 0.53 & 58.50 & 12.72 & 71.22 \\
\hline & & 2 & 24.00 & 0.206 & 58.50 & 0.30 & 2.16 & 0.62 & 58.20 & 16.74 & 74.94 \\
\hline & & 3 & 51.00 & 0.207 & 58.20 & -1.20 & 2.20 & 0.75 & 59.40 & 20.25 & 79.65 \\
\hline \multirow[t]{10}{*}{$90 \%$} & \multirow{4}{*}{$\begin{array}{lll}0-30 & 0-60\end{array}$} & 4 & 78.00 & 0.203 & 59.40 & 0.30 & 2.69 & 0.85 & 59.10 & 18.70 & 77.80 \\
\hline & & 5 & 100.00 & 0.204 & 59.10 & 2.40 & 1.96 & 0.31 & 56.70 & 8.99 & 65.69 \\
\hline & & 6 & 129.00 & 0.212 & 113.40 & -1.20 & 3.95 & 0.27 & 114.60 & 7.83 & 122.43 \\
\hline & & Harvest & 158.00 & 0.210 & 407.40 & $0.90^{\dagger}$ & $2.56^{\dagger}$ & $0.56^{\dagger}$ & $406.50^{\dagger \dagger}$ & $85.23^{\dagger \dagger}$ & $491.73^{\dagger \dagger}$ \\
\hline & \multirow{6}{*}{$0-60$} & 1 & 0.00 & 0.205 & 58.80 & 1.20 & 1.99 & 0.15 & 57.60 & 4.35 & 61.95 \\
\hline & & 2 & 29.00 & 0.207 & 116.40 & 1.20 & 3.03 & 0.21 & 115.20 & 7.98 & 123.18 \\
\hline & & 3 & 67.00 & 0.209 & 115.20 & -2.40 & 3.09 & 0.26 & 117.60 & 9.88 & 127.48 \\
\hline & & 4 & 105.00 & 0.205 & 117.60 & 1.20 & 3.06 & 0.26 & 116.40 & 9.88 & 126.28 \\
\hline & & 5 & 143.00 & 0.207 & 116.40 & 43.80 & 4.84 & 0.26 & 72.60 & 3.90 & 76.50 \\
\hline & & Harvest & 158.00 & 0.280 & 524.40 & $45.00^{\dagger}$ & $3.20^{\dagger}$ & $0.23^{\dagger}$ & $479.40^{\dagger \dagger}$ & $35.99^{\dagger \dagger}$ & $515.39^{\dagger \dagger}$ \\
\hline
\end{tabular}

$\dagger$ Average of data in column

$\dagger \dagger$ Sum of data in column relationship

Relationships were $0.291,0.247$ and $0.203 \mathrm{~cm}^{3} . \mathrm{cm}^{-3}$ for the 50,70 and $90 \%$ depletion rates during 158 days of wheat growing season. However actual $\theta_{i}$ values in column (5) does not necessarily equal laboratory estimated $\theta_{i}$ at the assumed depletion rates as shown in table (1) due to soil heterogeneity.

Value of $\theta_{i}$ before first irrigation was $0.205 \mathrm{~cm}^{3} . \mathrm{cm}^{-3}$ resulting in the highest DAIW value $(58.8 \mathrm{~mm})$ for the $30 \mathrm{~cm}$ depth and $50 \%$ depletion rate. DAIW for the first irrigation was assigned to be equal to required volume of applied irrigation water divided by plot area $\left(25 \mathrm{~m}^{2}\right)$ to replenish initial water content of the $30 \mathrm{~cm}$ ERZ to the field capacity $\left(0.401 \mathrm{~cm}^{3} \cdot \mathrm{cm}^{-}\right)$. For the remaining irrigations DAIW was calculated on the same basis for different treatments based on irrigation depth and $\theta_{i}$ values. When $\theta_{i}$ value at irrigation was greater than water content at $50 \%$ depletion $(0.291$ $\left.\mathrm{cm}^{3} \cdot \mathrm{cm}^{-}\right)$then water storage $(\Delta S)$ increases and $\Delta S$ was positive. High $\Delta S$ value $(25.5 \mathrm{~mm})$ was obtained during first irrigation to compensate for the deficit in $\theta_{i}$ values between first and second irrigations $\left(0.205\right.$ and $0.290 \mathrm{~cm}^{3} . \mathrm{cm}^{3}$ respectively). The lowest $\Delta S$ values was obtained at harvest since soil profile was undergoing drying process under dry and hot conditions for 22 days after last irrigation. DAIW values were calculated according to depletion rate, irrigation depth and $\theta_{i}$ values.

The piped - delivery irrigation system was equipped with water meters at the end of plot laterals measuring $\pm 0.001 \mathrm{~m}^{3}$ volume difference that facilitated applying exactly the right DAIW and eliminating run off losses during water application to experimental plots. Drainage losses were set equal to zero since total potential head at $30 \mathrm{~cm}$ was always lower than total potential head at $60 \mathrm{~cm}$ depth resulting in continuous upward water movement from the ground water $(90 \mathrm{~cm})$ towards ERZ (30 and or $60 \mathrm{~cm})$. Daily contribution rate to plant evapotransiration $\left(E T_{r}\right)$ which was accounted for by irrigation water was calculated according to the following formula: 


$$
E T_{r}=(D A I W-\Delta S) / T
$$

where $\mathrm{T}$ is time in days between two consecutive irrigations. Values of $E T_{r}$ are given in column (8). Contribution from DAIW to plant evapotransiration for each irrigation $\left(E T_{i r}\right)$ was calculated according to the following formula:

$$
E T_{i_{r}}=E T_{r} \times T
$$

and is given in column (10). Total contribution from DAIW to plant evapotransiration ( $E T_{i t}$ ) is the sum of $E T_{i r}$ 's for all irrigations and was calculated according to the following formula:

$$
E T_{i t}=\sum_{i=1}^{k} E T_{i r}
$$

where $\mathrm{i}$ is a counter for irrigation number. $E T_{i t}$ value for this treatment was $363.60 \mathrm{~mm}$ during the growing season.

High ET r rate, $2.22 \mathrm{~mm} . \mathrm{d}^{-1}$ during first irrigation is attributed to low canopy and high evaporation potential. Except last irrigation where soil profile was undergoing drying process for harvest a consistent increase in $E T_{r}$ values occurred with increasing irrigation number during the growing season reflecting increasing plant demands of water and nutrients for growth development.

Rate of daily contribution to evapotranspiration from ground water expressed as upward flux $\left(E T_{c}\right)$ for a soil layer designated by tensiometer placement was calculated according to Richards' equation as follows:

$$
E T_{c}=\int_{z_{n}}^{z_{n+1}} \frac{\partial \theta}{\partial T} d z
$$

where $z n$ and $\mathrm{zn}+1$ wer are the upper and lower boundaries of the $30 \mathrm{~cm}$ layer below ERZ. Boundaries of this layer were determined by tensiometer placement either at 30 and 60 or at 60 and $90 \mathrm{~cm}$ for 30 and $60 \mathrm{~cm} \mathrm{ERZ} \mathrm{respectively.} \partial \theta$ is the difference in volumetric water content which was calculated for the $30-60 \mathrm{~cm}$ layer according to following formula:

$$
\partial \theta=\left.\left(\theta_{60}-\theta_{30}\right)\right|_{T_{2}}-\left.\left(\theta_{60}-\theta_{30}\right)\right|_{T_{1}}
$$

where 30 and 60 represent the boundaries of the layer of the upward flux for the $30 \mathrm{~cm}$ ERZ. For the $60-90 \mathrm{~cm}$ layer $\partial \theta$ was calculated according to following formula:

$$
\partial \theta=\left.\left(\theta_{90}-\theta_{60}\right)\right|_{T_{2}}-\left.\left(\theta_{90}-\theta_{60}\right)\right|_{T_{1}}
$$

where 60 and 90 represent the boundaries of the layer of the upward flux for the $60 \mathrm{~cm}$ ERZ. $\partial T$ is the time difference in days between two consecutive irrigations.

Daily ETC values are given in column (9). Contribution from upward flux to evapotransiration for each irrigation
$\left(E T_{i c}\right)$ was calculated according to the following formula:

$$
E T_{i c}=E T_{c} \times T
$$

and is given in column (11). Total contribution from upward flux to plant evapotransiration ( $E T_{c t}$ ) is the sum of $E T_{i c}$ 's for all irrigations and was calculated according to the following formula:

$$
E T_{c t}=\sum_{i=1}^{k} E T_{i c}
$$

$E T_{c t}$ value for this treatment was $78.28 \mathrm{~mm}$ during the growing season which represents $21.5 \%$ of the $E T_{i t}$.

Actual rate of evapotranspiration for each irrigation, $E T_{i a}$ mm.d $\mathrm{d}^{-1}$, is defined to be the sum of $E T_{i r}$ and $E T_{i c}$ and was calculated according to the following formula:

$$
E T_{i a}=E T_{i r}+E T_{c r}
$$

and is given in column (12). $E T_{i a}$ value for the first irrigation was $39.75 \mathrm{~mm}$. Cumulative evapotarnspiration ( $E T_{\text {cum }}$ ) which represents actual evapotranspiration for the whole season was defined as the sum of $E T_{i a}{ }^{\prime} s$ according to following formula:

$$
E T_{\text {cum }}=\sum_{k=1}^{n} E T_{i a}
$$

Value of $\mathrm{ET}_{\text {cum }}$ for this treatment was $441.88 \mathrm{~mm}$ Measured data are given in columns 2 thru 5 while calculated values of the components of the water balance equation are given in columns 6 thru 12 as shown in table (1).

Only nine irrigations were applied when irrigation depth was switched from $30 \mathrm{~cm}$ to $60 \mathrm{~cm}$ at flowering. Components of the water balance for this treatment is given in table (1). Increasing irrigation depth from 30 to $60 \mathrm{~cm}$ increased DAIW by two folds, increased irrigation intervals of the last two irrigations as a result of increasing depth of ERZ from 30 to $69 \mathrm{~cm}$, decreased $E T_{c}$ and increased $E T_{r}$. Compared with $30 \mathrm{~cm}$ irrigation depth almost the same values were obtained for $\theta_{i}, E T_{c}, E T_{i}, E T_{i a}$ and $E T_{\text {cum }}$ during the first seven irrigations. Increasing irrigation depth to $60 \mathrm{~cm}$ along the growing season decreased number of irrigations and $E T_{c}$ and increased DAIW, ET ${ }_{i}$ and $E T_{\text {cum }}$ as shown in table (1).

Increasing depletion rate to $70 \%$ decreased number of irrigations to seven for the $30 \mathrm{~cm}$ depth and to six for the 30 60 and $60 \mathrm{~cm}$ depths and $\theta_{i}$ value to $0.247 \mathrm{~cm}^{3} . \mathrm{cm}^{-3}$ which in turn increased DAIW as shown in table (1). Switching irrigation depth from 30 to $60 \mathrm{~cm}$ increased $E T_{r}, E T_{c u m}$, and DAIW but significantly decreased $E T_{c}$. Averages of the $E T_{c}$ were $0.57,0.43$ and $0.20 \mathrm{~mm} \cdot \mathrm{d}^{-1}$ for the $30,30-60$ and $60 \mathrm{~cm}$ depths respectively. Decreasing average $E T_{c}$ values with 
increasing irrigation depth is best explained according to the Darcy's law where flux term between two points is proportional to the difference in total water potential divided by the distance (vertical in this study) between the two points at given water content or suction head values. Values of total potential head for 30,60 and $90 \mathrm{~cm}$ after 24 hours following irrigation ranged from -105 to $-75 \mathrm{~cm}_{2} \mathrm{O}$ as shown in fig. (2).

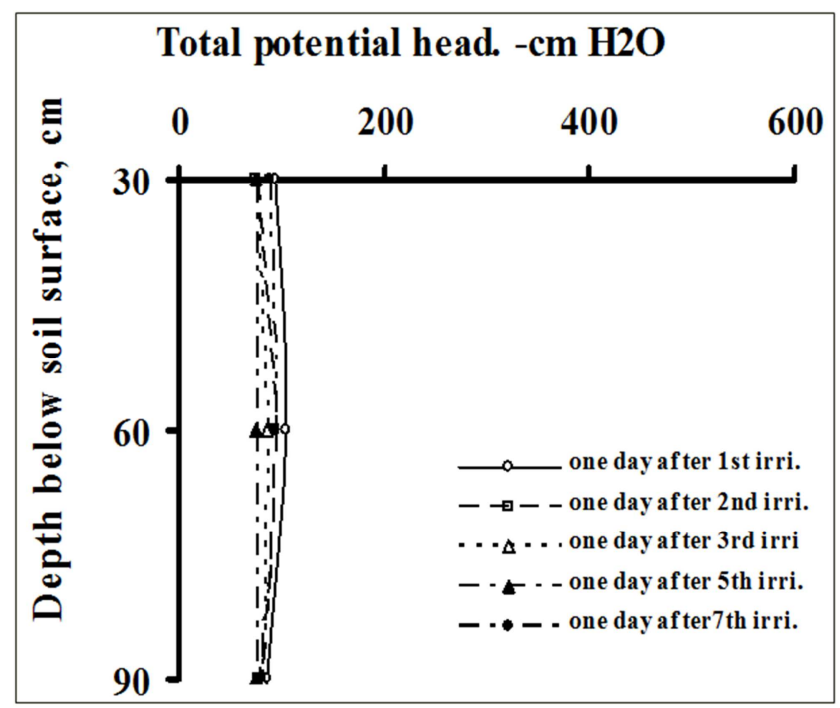

Fig. 2. Total potential head for the 30, 60 and $90 \mathrm{~cm}$ measured at $70 \%$ depletion rate and 24 hours after irrigations for the $30 \mathrm{~cm}$ irrigation depth.

Slight differences in total potential head values between different depths resulted in small hydraulic head gradient values. Fig. (2) also shows that the total potential head at the $90 \mathrm{~cm}$ depth is higher than total potential at the $60 \mathrm{~cm}$ depth for all irrigations. As a result the gradient values were around unity and the upward flux towards $60 \mathrm{~cm}$ decreased significantly. Pronounced differences in total potential values was developed between 30 and $60 \mathrm{~cm}$ depths as time proceeded after irrigation due to drying of the surface layer $(0-30 \mathrm{~cm})$ by evaporation from the soil surface and plant transpiration as shown in fig. (3).

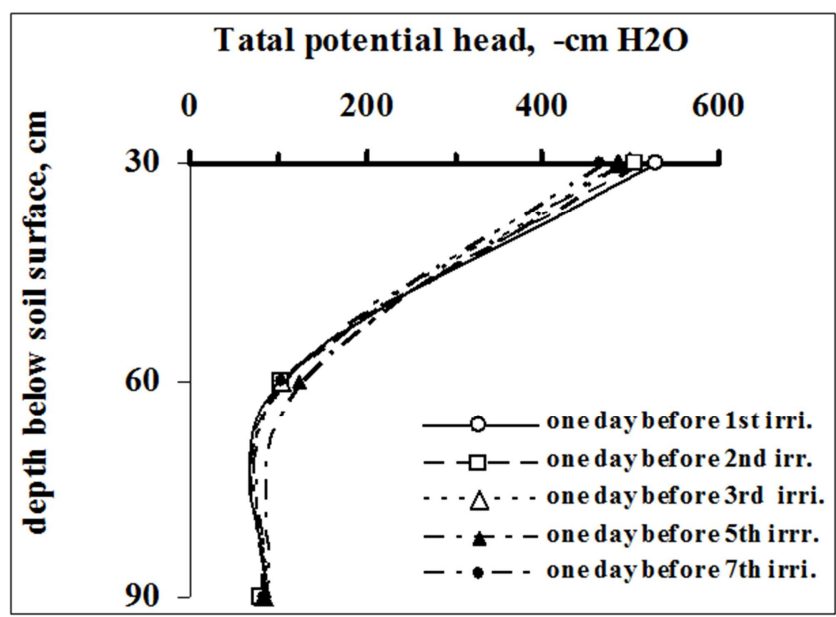

Fig. 3. Total potential head for the 30, 60 and $90 \mathrm{~cm}$ measured at $70 \%$ depletion rate and 24 hours before irrigations for the $30 \mathrm{~cm}$ irrigation depth.
Values of total water potential at the $60 \mathrm{~cm}$ depth were almost the same during the growing season since water table level ranged between 70 and $90 \mathrm{~cm}$. These findings agree with the findings of Salim and Rasheed (2012) who studied the movement of zero flux plane during irrigation under shallow water table condition. Compared with the distribution of total potential head shown in figure (3) different distribution patterns were obtained when the water table was deep enough from ERZ (Magdi et al. 2003, Joshi 1997).

Due to differences in $\Delta S$ values between irrigations $E T_{i t}$ value $(401.40 \mathrm{~mm})$ exceeded DAIW $_{\mathrm{t}}(394.50 \mathrm{~mm})$ for the 30 $60 \mathrm{~cm}$ depth by $6.90 \mathrm{~mm}$ which means that the depletion rate exceeded $70 \%$ from plant available water (see table 1) even average $E T_{c}$ value of the $30 \mathrm{~cm}$ depth $\left(0.57 \mathrm{~mm} \cdot \mathrm{d}^{-1}\right)$ was greater than $E T_{c}$ value at the $30-60 \mathrm{~cm}$ depths $\left(0.43 \mathrm{~mm} \cdot \mathrm{d}^{-1}\right)$. Increasing irrigation depth increased $\mathrm{ET}_{\mathrm{it}}$ to $341.40 \mathrm{~mm}$, $401.40 \mathrm{~mm}$ and $484.80 \mathrm{~mm}$ for the $30 \mathrm{~cm}, 30-60 \mathrm{~cm}$ and from 30-60 cm depths respectively.

Depleting 90\% from available water content decreased number of irrigations and increased DAIW. While $E T_{c}$ values decreased, $E T_{i}$ values increased with increasing irrigation depth. Highest $E T_{c}$ contribution to actual evapotranspiration, $96.59 \mathrm{~mm}$, occurred under $30 \mathrm{~cm}$ depth and decreased by $62.7 \%$ for the $60 \mathrm{~cm}$ depth treatments. Decreasing average $E T_{c}$ values with increasing irrigation depth is attributed to decreasing hydraulic head gradient between 60 and $90 \mathrm{~cm}$ compared with the gradient values between 30 and 60 as shown in fig. (4) for the $90 \%$ depletion rate.

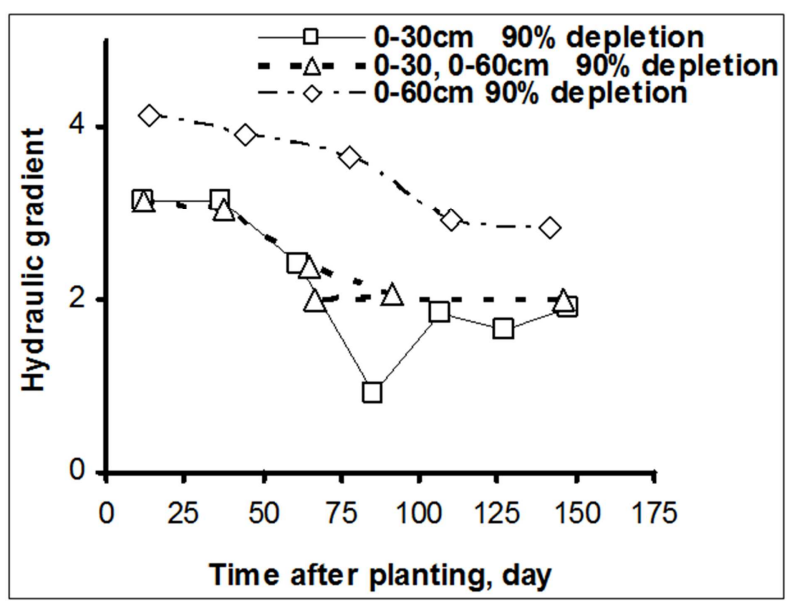

Fig. 4. Hydraulic head gradient of the layers $30 \mathrm{~cm}, 30-60 \mathrm{~cm}$ and $60-90 \mathrm{~cm}$ for 30, 30-60, and $60 \mathrm{~cm}$ irrigation depths respectively at 90\% depletion rate.

The highest DAIW, $524.40 \mathrm{~mm}$, was applied for the $60 \mathrm{~cm}$ depth resulting in the highest positive $\Delta S$ value ( 45.00 $\mathrm{mm}$ ). It seems that the fifth irrigation was not necessary for plant growth since it was applied before 15 days from harvest where the grains were at the drying stage.

The highest $\mathrm{ET}_{\mathrm{i}}$ contribution to actual evapotranspiration, $496.50 \mathrm{~mm}$ occurred under $50 \%$ depletion and $60 \mathrm{~cm}$ depth 
and decreased by $27.2 \%$ for the $30 \mathrm{~cm}$ depth. The highest $E T_{\text {cum }}$ value $(512.22 \mathrm{~mm})$ obtained under $50 \%$ depletion rate and $60 \mathrm{~cm}$ irrigation depth. However differences in evapotranspiration values doesn't necessarily respond to differences in growth factors and yield of wheat.

\section{Conclusions}

Under water scarcity circumstances and shallow water table condition, a precise assessment of flow processes occurring during the water distribution and redistribution in the vadose zone is required to determine daily contribution rates to plant evapotranspiration from the soil water balance equation and to minimize water losses and maximize capillary flux contributions which in turns increase water productivity. Results of this study can be used as a field practice for maximizing contribution from shallow water table to crop evpotranspiration when considering depletion rate and irrigation depth.

\section{References}

[1] Al-shahrabli. Q. 2009. Surface Water Resources in Iraq: Current and Future Scenarios. Iraqi Soil Salinity and Water Management Conference. July $15^{\text {th }}-17^{\text {th }} 2009$, Alrashid Hotel. Baghdad, Iraq.

[2] Brown, I., Dunn, S., Matthews, K., Poggio, L., Sample, J. and Miller, D. 2012. Mapping of water supply-demand deficits with climate change in Scotland: land use implications, CREW report 2011/CRW006. Available online at: www.crew.ac.uk/publications/water-supply-demand-balanceand-climate-change.

[3] Eiasu, B. K., J.M. Steyn and P. Soundy. 2006. Rose-scented geranium (Pelargonium capitatum $\times \mathrm{P}$. radens) growth and essential oil yield response to different soil water depletion regimes. Agricultural Water Management, 96(6): 991-1000. Hanks, R. J. and G. L. Ashcroft. 1980. Applied Soil Physics. Advanced series in Agricultural Sciences8. Sprinkler-Verlag. Berlin Heidelberg New York Tokyo.

[4] Jalota, S. K., A. Sood, G.B.S. Chahal and B.U. Choudhury. 2006. Crop water productivity of cotton (Gossypium hirsutum L.)-wheat (Triticum aestivum L.) system as influenced by deficit irrigation, soil texture and precipitation . Agricultural Water Management, 84(2): 137-146.
[5] Joshi, B. 1997. Estimation of diffuse vadose zone soil-water flux in a semi- arid region. PhD thesis, Department of Agriculture and Bioresources Engineering. University of Saskatchewan, Canada.

[6] Khalil, M., M. Sakai, M. Mizoguchi and T. Miyazaki. 2003. Current and Prospective Applications of Zero Flux Plane (ZFP) Method. J. Jpn. Soc. Soil Phys. J. Jpn . Soc. Soil Phys. 95: 75-90.

[7] Leib, B.G., M. Hattendorf, T. Elliott and G. Matthews. 2002. Adoption and adaptation of scientific irrigation scheduling: trends from Washington, USA as of 1998. Agricultural Water Management 55: 105-120.

[8] Moiwo J. P., F. Tao and W. lub. 2011. Estimating soil moisture storage change using quasi-terrestrial water. Agriculture Water management. 102(1)25-34.

[9] Odhiambo, J. J. O. and A.A. Bomke. 2007. implications for cover crop management in south coastal British Columbia Agricultural Water Management, Volume 88, Issues 1-3, 16 March 2007, Pages 92-98 OJuana Paul Moiwo J. P.and, F.Tao and W. Lu. 2011. Estimating soil moisture storage change using quasiterrestrialwater balance method. Agricultural Water Management 102(1): 25-34.

[10] Owonubi, J. J. and S. Abduimumin. 1991. Review of soil water balance studies in the Sudano-Sahelian zone of Nigeria. Proceedings of the Niamey Workshop, February 1991 . IAHS 1991.

[11] Quality 40:1652-1660.

[12] Richards, L.A. 1931. Capillary conduction of liquids through porous mediums. Physics 1(5):318-333.

[13] Saini, B. C. and B.P. Ghildyal. 1977. Seasonal water use by winter wheat grown under shallow water table conditions Original Research Article Agricultural Water Management, Volume 1, Issue 3, November 1977, Pages 263-276.

[14] Saleh, D.K. 2010, Stream gage descriptions and stream flow statistics for sites in the Tigris River and Euphrates River Basins, Iraq: U.S. Geological Survey Data Series 540, 146 p.

[15] Salim S. B. and T. L. Rasheed. 2013. Water balance in cultivated and uncultivated soil. J. Sci. Tecnology. 4(3):85-93.

[16] Strauss, C., T. Harter and M. Radke. 2011. Effects of pH and Manure on Transport of Sulfonamide Antibiotics in Soil. Journal of Environmental Quality 40:1652-1660. 